\title{
Production of seaweed snack from pangasius (Pangasius hypophthalmus) fillet by-products
}

\author{
Kha M. Le, \& Binh Q. Truong* \\ Department of Aquatic Product Processing, Nong Lam University, Ho Chi Minh City, Vietnam
}

ARTICLE INFO
Research Paper
Received: August 02, 2019
Revised: September 13, 2019
Accepted: October 01, 2019
Keywords
Pangasius by-products
Seaweed
Snack
Value-added products
*Corresponding author
Truong Quang Binh
Email: tqbinh@hcmuaf.edu.vn

\begin{abstract}
By-products from pangasius fillet processing are a good source to create a new value-added product such as snack. In this study, the effects of seaweed ratio, seasoning ratio, drying and frying conditions on sensory, texture, water holding capacity and moisture of product were investigated to find the best quality of the product.

The results showed that seaweed-added products had a better texture as compared to seaweed non-added products. However, seaweed addition $>$ $3 \%$ weakened the product's texture. The appropriate seaweed ratio was $1 \%$. The spice ratio $(0.2 \%$ salt : $0.3 \%$ sugar : $0.1 \%$ monosodium glutamate (MSG) : $0.1 \%$ chili powder) was most favoured. The product (size $30 \times$ $30 \mathrm{~mm}$ and thickness of $2 \mathrm{~mm}$ ) was dried at $80^{\circ} \mathrm{C}$ in $105 \mathrm{~min}$, to the final moisture of $8.17 \% \pm 0.04$. The product was fried by shortening for $20 \mathrm{sec}$ at $180^{\circ} \mathrm{C}$ and resulted in the highest sensory quality.
\end{abstract}

Cited as: Le, K. M., \& Truong, B. Q. (2019). Production of seaweed snack from pangasius (Pangasius hypophthalmus) fillet by-products. The Journal of Agriculture and Development 18(6), 23-29.

\section{Introduction}

In Vietnam, more than 1,000,000 tons of pangasius by-products (Pangasius hypophthalmus) need to be handled each year (VASEP, 2019). In particular, the source of pangasius by-products is stable, high quality and suitable to create valueadded products.

One of the requirements in the production of pangasius snacks mixed with seaweed is the texture of the raw material after grinding to create gel (paste), this process is important to create products with the best texture. The gelling capacity of food proteins is an important functional attribute for food manufacturing (Zayas, 1997). Protein gelation determines the organolep- tic properties of food and its texture, which, in turn, determines whether a product is accepted by the consumer (Mulvihill \& Kinsella, 1987). Gelation provides texture to the food, improves water absorption, induces thickening effects, stabilizes the system and determines the appearance of food (Kinsella et al., 1985; Damodaran, 1994).

A gel is an intermediate phase between a solid and a liquid. Technically, it is defined as a substantially diluted system that exhibits no steady flow. Protein gelation refers to the transformation of protein from the sol state (viscous material) to a gel-like state (elastic material) (Haug \& Draget, 2011). A gel is a three-dimensional structure that engages and immobilizes the liquid phase inside itself. Gels are obtained when pro- 
teins are denatured (Mulvihill \& Kinsella, 1987; Fligner \& Mangino, 1991; Pilosof, 2000). Gelation is a phenomenon that occurs via crosslinking of polymers using chemical interactions. Therefore, the formed three-dimensional structures, which can trap water and low-molecular-weight substances, are called gels (Mulvihill \& Kinsella, 1987; Fligner \& Mangino, 1991; Pilosof, 2000). A simple definition could be that protein gelation is an aggregation of denatured molecules with a certain degree of order, resulting in the formation of a continuous network (Wong, 1989). Gelation is a two-step process: denaturation and aggregation (Kinsella et al., 1985; Matsumura \& Mori, 1996). The mechanism by which proteins form a gel is not well understood. However, two theories are proposed. First, the Flory-Stockmayer theory suggests that a gelation is a sudden event that is achieved via some degree of crosslinking between polymers and reaches a critical value called the gel point, in which the viscosity diverges to infinity. Second, the Percolation theory assumes that monomers form small aggregates and, at some point, reach the gel point (Pilosof, 2000).

Seaweeds are major coastal resources that are valuable to human consumption and the environment in many countries. Edible seaweeds were widely exploited and consumed in Vietnam with the production of $600,000-700,000$ tons of dried seaweed/year (Hoang, 2016). Thus, it is a huge demand to develop new products from seaweed. Seaweed has very little fat, ranging from $1-5 \%$ of dry matter, although seaweed lipids have a higher proportion of essential fatty acids than land plants. Seaweed has high fiber content, making up $32 \%$ to $50 \%$ of dry matter. The soluble fiber fraction accounts for $51-56 \%$ of total fibers in green (ulvans) and red algae (agars, carrageenans and xylans) and $67-87 \%$ in brown algae (laminaria, fucus, and others). Soluble fibers are generally associated with having cholesterol-lowering and hypoglycemic effects (Dharmananda, 2002).

There are many studies on gelation of fish protein such as research for tilapia snack production; study of factors influencing the gel-forming process of fish protein; research to improve gelforming ability; studies on surimi production; research into food production from fish protein gel (fish balls, surimi, fish cakes, ...). However, the studies on the production of combined fish protein and seaweeds are still limited. In this study, a new value-added product from pangasius by-product and seaweed was developed in snack form.

\section{Materials and Methods}

\subsection{Materials}

Pangasius by-products in the fillet process were purchased at GODACO (My Tho City, Tien Giang Province, Vietnam), frozen by ice and transported to Nong Lam university in $3-3.5$ hours.

Seaweed is grinded and used in dried form (Ao Nori brand, Japan) (Figure 1).
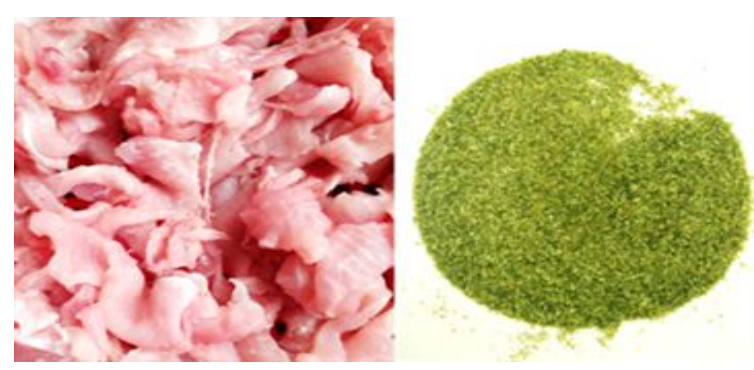

Figure 1. The pangasius by-product after removing fat, skin and bones (A) and dried seaweed used for food (B).

\subsection{Methods}

\subsubsection{Gel preparation}

Pangasius by-product (after removing fat, skin and bones) was washed, drained and minced with meat grinder.

Fish by-product $(1 \mathrm{~kg})$ was minced for $30 \mathrm{sec}-$ onds and kept cool during the grinding process by adding $10 \%-15 \%$ of clean ice. Salt $(\mathrm{NaCl})$ $0.1 \%$ was added to the by-product to increase the gelling effect of the product. Seaweed at 0 , 1 and $3 \%$ was also added before grinding step. Spice was also added to the paste at 3 different ratio as following:

- $0.2 \%$ salt : $0.3 \%$ sugar : $0.1 \%$ MSG : $0.1 \%$ chili powder

- $0.5 \%$ salt: 0,5\% sugar: $0.1 \%$ MSG: $0.1 \%$ chili powder

- $0.2 \%$ salt: $0.3 \%$ sugar: $0,1 \%$ MSG: $0.1 \%$ chili powder

Minced fish by-product (size $30 \times 30 \mathrm{~mm}$, the thickness of $2 \mathrm{~mm}$ and an average weight of 1.65 
g) was cooked at $90^{\circ} \mathrm{C}$ for 5 min. After cooking, the fish cake was dried at 3 different conditions at $80^{\circ} \mathrm{C}$ for $105 \mathrm{~min} ; 70^{\circ} \mathrm{C}$ for $150 \mathrm{~min}$ and $60^{\circ} \mathrm{C}$ for $200 \mathrm{~min}$. Finally, dried fish cake was fried in shortening at $180^{\circ} \mathrm{C}$ for $10,15,20$ and $30 \mathrm{sec}$ (Figure 2).

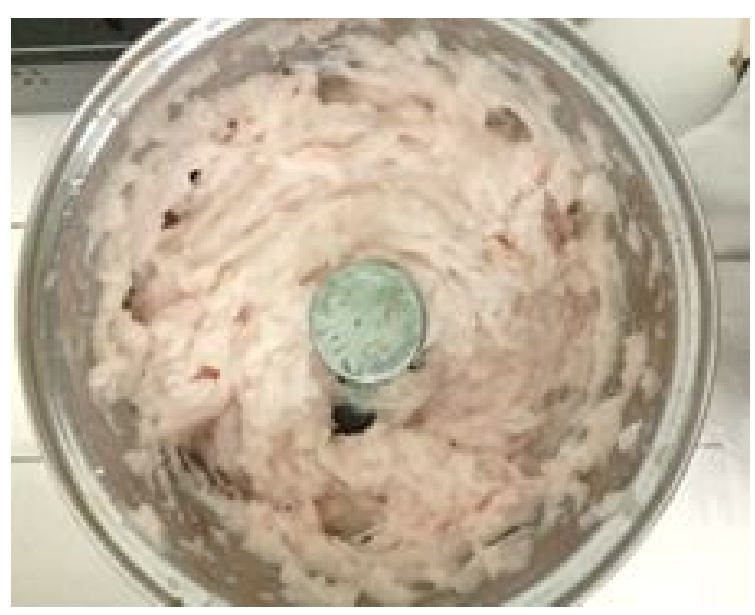

Figure 2. Pangasius by-products was minced to create gel.

\subsubsection{Texture profile analysis (TPA)}

Fish gels were cut into cylinder $(30 \mathrm{~mm}$ in diameter and $2 \mathrm{~mm}$ thick). Brookfield food texture analyzer (CT3, USA) was used to test for TPA. TPA was measured by a cylindrical-shaped probe, $12.7 \mathrm{~mm}$ in diameter. Fish samples were compressed at $1 \mathrm{~mm} / \mathrm{s}$ to $75 \%$ of their original height.The sample was compressed to $75 \%$ of height.

\subsubsection{Water hold capacity (WHC)}

WHC of fish gels was determined by centrifugation (Z 216 MK, Germany). Sample was wrapped in filter paper to absorb water then centrifuged at speed of $6000 \mathrm{r} / \mathrm{min}$ in $20 \mathrm{~min}$. Samples were weighed before and after centrifugation to calculate WHC as following:

$\mathrm{WHC}(\%)=\frac{\mathrm{W}_{0}-\Delta \mathrm{W}}{\mathrm{W}_{0}} \times 100($ Skipnes et al., 2007)

With:

$$
\mathrm{W}_{0}=\frac{\mathrm{v}_{0}}{\mathrm{v}_{0}+\mathrm{D}_{0}} \times 100
$$

and

$$
\Delta \mathrm{W}=\frac{\Delta \mathrm{v}_{0}}{\mathrm{v}_{0}+\mathrm{D}_{0}} \times 100
$$

$\mathrm{v}_{0}$ : Initial water content of the sample

$\Delta \mathrm{v}_{0}$ : Difference in water content of the sample, before and after centrifugation

$\mathrm{D}_{0}$ : Initial dry mass of the sample. The dry mass can be determined gravimetrically.

\subsubsection{Moisture}

About $100 \mathrm{~g}$ of sample was analysed for moisture by using the moisture analyzer (AND MX50, Japan) after drying. Each treatment was analysed in triplication.

\subsubsection{Sensory analysis}

The sensory of final products was investigated following the method of Ha (2006). Sensory experiments were arranged in a well-ventilated room with no strange smell, sufficient light, sensory time from $8-11 \mathrm{~h}$, the age of the panels from 18 to 23 years old, the ratio of male to female is 1:1. The test sample is placed on a white porcelain plate, each of which is encoded with 3 random digits. The evaluation score following 9point category scale.

\subsubsection{Statistical analysis}

All analytical measurements were carried out in triplications and the results were reported as mean values \pm standard deviations. Data were analysed by one way analysis of variance (ANOVA) and least significant difference (LSD) using SPSS software version 21.0 (IBM Corp., United States).

\section{Results and Discussion}

The results on the texture of the product are showed in Table 1. The difference in hardness, cohesiveness, springiness, gumminess, and chewiness among the treatments was insignificant $(P>$ $0.05)$. On average, NT1 had the highest hardness of $2.92(\mathrm{~N})$, and NT3 had the lowest hardness of $2.59(\mathrm{~N})$. For cohesiveness, NT3 has the highest cohesiveness of 0.83 compared to the rest of the treatment, the added seaweed may increase the cohesiveness of the product, but this increase was negligible. The springiness of NT1 was lowest $(1.19 \mathrm{~mm})$ and the highest was NT2 $(1.28 \mathrm{~mm})$, the addition of seaweed increased the springiness. However, the springiness of the sample decreased at $3 \%$ of seaweed addition. For gummi- 
Table 1. Results of texture profile analysis of fish gels

\begin{tabular}{lccc}
\hline Treatment & NT1 & NT2 & NT3 \\
& 0\% seaweed & 1\% seaweed & 3\% seaweed \\
\hline Hardness (N) & $2.92 \pm 0.27$ & $2.70 \pm 0.16$ & $2.59 \pm 0.18$ \\
Cohesiveness & $0.82 \pm 0.06$ & $0.82 \pm 0.01$ & $0.83 \pm 0.36$ \\
Springiness (mm) & $1.19 \pm 0.09$ & $1.28 \pm 0.04$ & $1.25 \pm 0.07$ \\
Gumminess (N) & $2.36 \pm 0.17$ & $2.22 \pm 0.14$ & $2.15 \pm 0.21$ \\
Chewiness (mJ) & $2.83 \pm 0.25$ & $2.85 \pm 0.25$ & $2.70 \pm 0.22$ \\
\hline
\end{tabular}

Different letters $(\mathrm{a}, \mathrm{b}, \mathrm{c})$ in the same row indicate significant differences $(P \leq 0.05)$.

Table 2. Results of texture profile analysis of fish gels

\begin{tabular}{lccc}
\hline Treatment & NT1 & NT2 & $\begin{array}{c}\text { NT3 3\% } \\
\text { seaweed }\end{array}$ \\
\hline WHC (\%) & $45.11^{\mathrm{a}} \pm 1.09$ & $44.76^{\mathrm{a}} \pm 0.27$ & $29.28^{\mathrm{b}} \pm 0.72$ \\
\hline Different letters $(\mathrm{a}, \mathrm{b}, \mathrm{c})$ in the same column indicate significant differences $(P \leq 0.05)$.
\end{tabular}

ness, NT1 exhibited maximum gumminess $(2.36$ $\mathrm{N})$. The percentage of seaweed added is inversely proportional to the gumminess with the larger the percentage of seaweed addition, the lower the gumminess. With an exerted force of $2.85(\mathrm{~mJ})$, NT2 had the highest chewiness and the lowest was NT3: 2.7 (mJ). The chewiness was the characteristic quantity for the solidity of food. The chewiness of NT2 was also higher than that of NT1. The addition of seaweed makes the texture of the sample more solid. However, when seaweed was added too much, it will affect the bonding of the protein gel. Therefore, the structure of gel was weakened and unstable leading to the lower chewiness of NT3 as compared to NT2.

In general, the addition of seaweed could change the texture of the samples, although there was no significant difference.

\subsection{WHC of seaweed snack product}

The results showed that the WHC value of NT1 (0\% seaweed) and NT2 (1\% seaweed) were similar (Table 2). However, the WHC of NT3 (3\% seaweed) was significantly lower than NT1 and NT2 $(P<0.05)$.

WHC of fish gels was decreased with the increase in seaweed addition to the product. The decrease in WHC between treatments can be explained by seaweed addition prevented the formation of protein networks, making protein bondings unstable. The reduction of space gaps decreased the ability to hold water inside. It can be concluded that with a less stable spatial structure, NT3 had poor texture and not as stable as NT1 and NT2. From the results of TPA and
WHC, NT2 (1\% seaweed addition) was selected for the next step of our study.

\subsection{Effects of seasoning ratio on sensory qual- ity of snack product}

The difference in sensory scores between the treatments was significant among treatments $(P$ $<0.05)$. NT3 was highest with an average score of 6.95 ; NT2 had the lowest mean score of 5.65 (Table 3).

In this experiment, NT3 had the lowest salt addition of $0.2 \%$ compared to other treatments. However, the sensory quality of NT3 was most favoured by the panels. This was also under the tendency of consumers to reduce salt in processed products and in the diet, which was also recommended by WHO. Therefore, treatment $3(0.2 \%$ salt: $0.3 \%$ sugar: $0.1 \%$ MSG: $0.1 \%$ chili powder $)$ was used for seasoning of the product.

\subsection{Effect of drying on the moisture of the product}

As shown in Table 4, NT2 has the highest moisture of $8.49 \%$. NT1 and NT2 had the same moisture of $8.17 \%$ and significantly lower than NT2 $(P<0.05)$. In the drying process, the hot air reduces the relative moisture of the medium, increasing driving force for the drying process. In this period, the heated material and the higher temperature of the drying medium increases the rate of water diffusion from the inside of the material to the surface of the drying material and into the environment, by molecular diffusion leading to the reduction the moisture of the product. 
Table 3. Results on sensory test of snack product

\begin{tabular}{lccc}
\hline \multirow{2}{*}{ Treatment } & NT1 & NT2 & NT3 \\
& $(0.3 \%$ salt: $0.5 \%$ & $(0.5 \%$ salt: $0.5 \%$ & $(0.2 \%$ salt: $0.3 \%$ \\
& sugar: $0.1 \%$ MSG: & sugar: $0.1 \%$ MSG: & sugar: $0.1 \%$ MSG: \\
& $0.1 \%$ chili powder $)$ & $0.1 \%$ chili powder $)$ & $0.1 \%$ chili powder $)$ \\
\hline Taste & $5.75^{\mathrm{b}} \pm 0.71$ & $5.65^{\mathrm{c}} \pm 1.18$ & $6.95^{\mathrm{a}} \pm 0.60$ \\
\hline Different letters $(\mathrm{a}, \mathrm{b}, \mathrm{c})$ in the same row indicate significant differences $(P \leq 0.05)$. &
\end{tabular}

Table 4. Moisture of product after drying

\begin{tabular}{lccc}
\hline Treatment & NT1 & NT2 & NT3 \\
& $\left(80^{\circ} \mathrm{C}, 105 \mathrm{~min}\right)$ & $\left(70^{\circ} \mathrm{C}, 150 \mathrm{~min}\right)$ & $\left(60^{\circ} \mathrm{C}, 200 \mathrm{~min}\right)$ \\
\hline WHC (\%) & $45.11^{\mathrm{a}} \pm 1.09$ & $44.76^{\mathrm{a}} \pm 0.27$ & $29.28^{\mathrm{b}} \pm 0.72$ \\
\hline Different letters $(\mathrm{a}, \mathrm{b}, \mathrm{c})$ in the same row indicate significant differences $(P \leq 0.05)$.
\end{tabular}

Table 5. Sensory results of snack product at different frying conditions

\begin{tabular}{lcccc}
\hline Treatment & $\begin{array}{c}\text { NT1 } \\
(10 \mathrm{sec})\end{array}$ & $\begin{array}{c}\text { NT2 } \\
(15 \mathrm{sec})\end{array}$ & $\begin{array}{c}\text { NT3 } \\
(20 \mathrm{sec})\end{array}$ & $\begin{array}{c}\text { NT4 } \\
(30 \mathrm{sec})\end{array}$ \\
\hline Smell & $5.25^{\mathrm{c}} \pm 0.44$ & $6.30^{\mathrm{b}} \pm 0.47$ & $7.40^{\mathrm{a}} \pm 0.50$ & $4.00^{\mathrm{d}} \pm 0.00$ \\
Taste & $4.25 \mathrm{c} \pm 0.44$ & $6.25 \mathrm{~b} \pm 0.44$ & $7.30^{\mathrm{a}} \pm 0.57$ & $3.35^{\mathrm{d}} \pm 0.48$ \\
Colour & $5.10^{\mathrm{c}} \pm 0.55$ & $5.80^{\mathrm{b}} \pm 0.61$ & $7.30^{\mathrm{a}} \pm 0.80$ & $3.33^{\mathrm{d}} \pm 0.57$ \\
Texture & $4.25^{\mathrm{c}} \pm 0.63$ & $6.25^{\mathrm{b}} \pm 0.44$ & $7.45^{\mathrm{a}} \pm 0.32$ & $3.20 \mathrm{~d} \pm 0.41$ \\
Overall score & $4.70^{\mathrm{c}} \pm 0.47$ & $6.20^{\mathrm{b}} \pm 0.41$ & $7.75^{\mathrm{c}} \pm 0.44$ & $3.50^{\mathrm{d}} \pm 0.51$ \\
\hline
\end{tabular}

Different letters $(\mathrm{a}, \mathrm{b}, \mathrm{c})$ in the same row indicate significant differences $(P \leq 0.05)$.

This moisture reduction also changed the texture of the treatments from the original texture of the gel form to a dry and hard texture (Figure 3). With significant shorter drying time as compared to NT3, drying condition at NT1: $80^{\circ} \mathrm{C}$ and 105 min was chosen for the product.
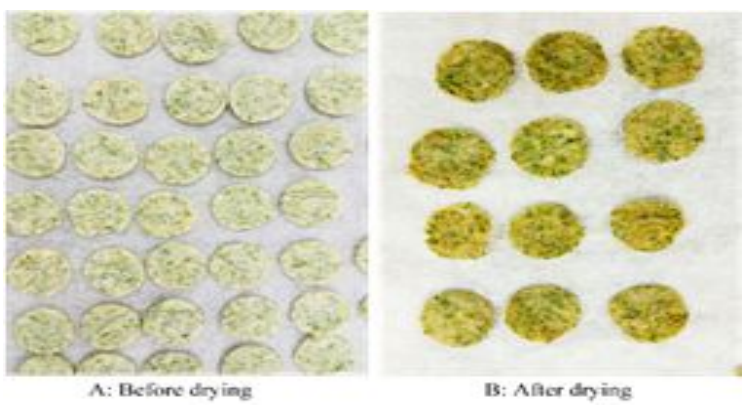

Figure 3. Samples before drying (A) and after drying (B), with changes in color, mass, moisture and texture.

\subsection{Effect of frying condition on sensory qual- ity of product}

The results of the sensory evaluation are showed in Table 5 . The difference between the treatments was significant $(P<0.05)$. The fry- ing process changed the color, smell, taste, texture and moisture content of products. The 20second frying treatment has the highest overall score (7.75) and the lowest overall score of 30 seconds (3.50). The sensory score of the frying treatment at 20 seconds in terms of smell, taste, texture and color were 7.40, 7.30, 7.45 and 7.30, respectively.

The temperature of $180^{\circ} \mathrm{C}$ (greater than $120^{\circ} \mathrm{C}$ ) is the condition for phase 3 reaction of the Maillard reaction. High temperature accelerates the chemical reaction and increases the rate of water evaporation in the food thereby speeding up the maillard Maillard reaction. When frying for a long time, the amino acids and sugars are converted to aldehydes, nitrogen-containing compounds, and alcohols condensate, making food bitter and dark (Mallawaarachchi., 2017) (Figure 4 ). These conditions also changesd the sensory quality of the samples.

The treatment with the shortest time of $10 \mathrm{sec}$ (NT1) had a brighter color and typical flavor of the fried product, but had the toughest texture. Because the frying time was not enough to completely removed the water, so the texture of the product was not crispy and toughed.

For NT3 frying at $20 \mathrm{sec}$, the score results 

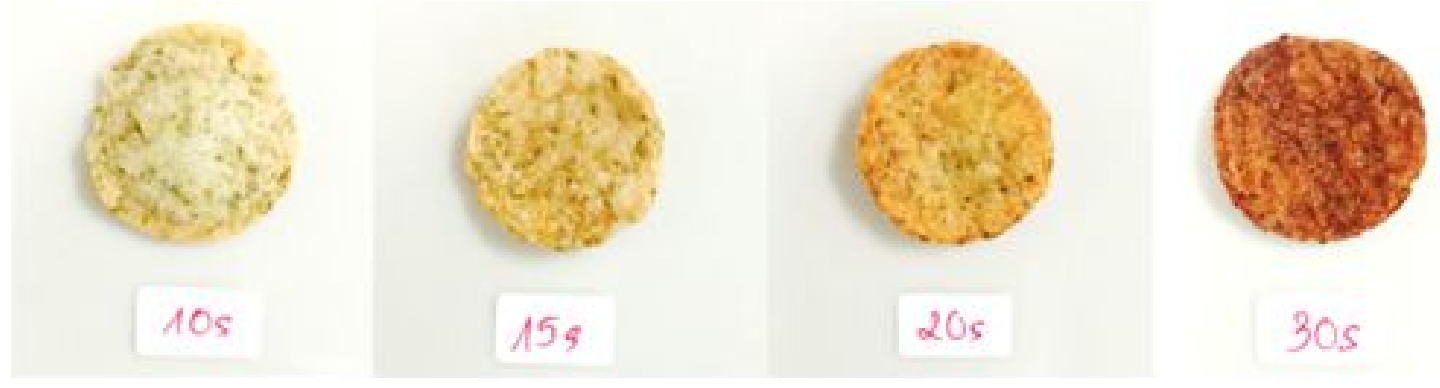

Figure 4. Product color at $180^{\circ} \mathrm{C}$ and different frying time (from left to right): $10,15,20$ and 30 sec.

showed a superior in smell, color, taste and texture as compared to other treatments (Figure 5). Thus, frying time at $20 \mathrm{sec}$ is selected. This frying time is enough to ensure the good quality of the product. If frying time is shorter than $20 \mathrm{sec}$, the water is not completely removed from the sample and reduced the crispy of product. If frying time is longer than $20 \mathrm{sec}$, the color is dark and bitter with a burnt odor which is not suitable for consumption.

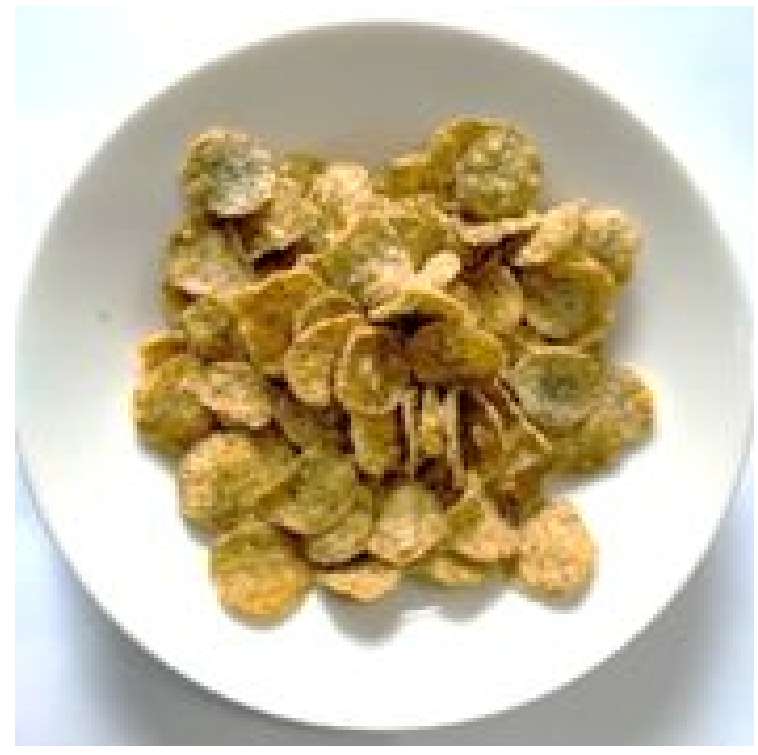

Figure 5. Final seaweed pangasius snack product.

\section{Conclusions}

The results showed that seaweed-added products resulted in better texture as compared to seaweed non-added products. However, seaweed addition $>3 \%$ weakened the product's texture. The appropriate seaweed ratio was $1 \%$. The ap- propriate spice ratio was $0.2 \%$ salt: $0,3 \%$ sugar: 0.1\% MSG: $0.1 \%$ chili powder: $0.1 \%$ seaweed flavor powder and vegetable oil. The product (size $30 \times 30 \mathrm{~mm}$ and thickness of $2 \mathrm{~mm}$ ) was dried at $80^{\circ} \mathrm{C}$ in $105 \mathrm{~min}$ to the final moisture of $8,17 \%$. The product was fried by shortening for $20 \mathrm{sec}$ at $180^{\circ} \mathrm{C}$ resulted in the highest sensory value. For further study, more combination of spices should be investigated to create fish snack product with diverse taste to meet the demands of customer

\section{References}

Damodaran, S. (1994). Structure-function relationship of food proteins. In Hettiarachchy, N. S., and Ziegle, G. R. (Eds.). Protein functionality in food systems ( $1^{\text {st }}$ ed., 1-38). New York, USA: Marcel Dekker.

Dharmananda, S. (2002). The nutritional and medicinal value of seaweeds used in chinese medicine. Retrieved January 07, 2019, from http://www.itmonline.org/arts/seaweed.htm.

Fligner, K. L., \& Mangino, M. E. (1991). Relationship of composition to protein functionality. In Parris, N. and Barford, R. (Eds.). Interactions of food proteins ( $1^{\text {st }}$ ed., 1-12). Washington, USA: American Chemical Society.

Ha, D. T. (2006). Food sensory analysis techniques. Ha Noi, Vietnam: Science and Technics Pulishing House.

Haug, I. J., \& Draget, K. I. (2011). Gelatin. In Phillips, G. O., and William, P. A. (Eds.). Handbook of food proteins ( $1^{\text {st }}$ ed., 92-114). Cambridge, UK: Woodhead Publishing.

Hoang, M. (2016). Development of seaweed industry in Vietnam. Retrieved January 07, 2019, from http://cesti.gov.vn/images/cesti/files/STINFO/Nam 2016/So9/trang17-18.pdf.

Kinsella, J. E., Damodaran, S., \& German, J. B. (1985). Physicochemical and functional properties of oilseed proteins with emphasis on soy proteins. In Altshul, A. M., and Wilcke, H. L. (Eds.). New proteins foods: Seed storage proteins ( $1^{\text {st }}$ ed., 107-179). New York, USA: Academic Press. 
Mallawaarachchi, V. (2017). Maillard reactionThe science of browning, flavoring and aroma. Retrieved January 07, 2019, from https://vijini.medium.com/maillard-reactionthe-science-of-browning-flavoring-and-aroma1605133960ae.

Matsumura, Y., \& Mori, T. (1996). Gelation. In Hall, G. M. (Ed.). Methods to testing protein functionality ( $1^{\text {st }}$ ed., 76-109). New York, USA: Blackie Academic \& Professtional.

Mulvihill, D. M., \& Kinsella, J. E. (1987). Gelation characteristics of whey protein and b-lactoglobulin. Food Technology 41, 102-111.

Pilosof, A. M. R. (2000). Gelificación. In Pilosof, A. M. R., and Bartholomai, G. B. (Eds.). Caracterizacion funcional $y$ estructural de proteinas ( $1^{\text {st }}$ ed., 75-77). Buenos Aires, Argentina: Eudeba.
Skipnes, D., Østby, M. L., \& Hendrickx, M. E. (2007). A method for characterising cook loss and water holding capacity in heat treated cod (Gadus morhua) muscle. Journal of Food Engineering 80(4), 1078-1085.

VASEP (Vietnam Association of Seafood Exporters and Producers). (2019). Reference list Vietnam association of seafood exporters and producers, 2019. Gold mine from aquatic by-products. Retrieved August 02, 2019, from http://vasep.com.vn/Tin-Tuc/1112_54186/Movang-tu-phu-pham-thuy-san.htm.

Wong, D. W. S. (Ed.). (1989). Mechanism and theory in food chemistry ( $2^{\text {nd }}$ ed.). New York, USA: Springer International Publishing.

Zayas, J. F. (1997). Functionality of proteins in food $\left(1^{\text {st }}\right.$ ed.). New York, USA: Springer-Verlag Berlin Heidelberg. 